\title{
PLAGIOLEPIS XENE STÄRCKE, THE FIRST INQUILINE ANT FROM THE BALEARIC ISLANDS (SPAIN)
}

\author{
By Espadaler, X. ${ }^{1}$ And Cagniant, $\mathrm{H}^{2}{ }^{2}$
}

\section{INTRODUCTION}

Parasitic ants (sensu Wilson, 1971) are rarely found though they seem to be fairly abundant when searched for specifically (Buschinger, 1987). Populations of these peculiar ants seem to be highly dispersed; this implies little gene flow between widely separated populations. If this is generally the case it would potentially lead to increasing speciation rates. The taxonomy of Mediterranean Plagiolepis has not been revised since Santschi (1920) and Emery (1921) and recent findings suggest that new species remain to be described. A new species with apterous males and females, has been found in El Hierro, Canary Islands (unpublished) and three new parasitic Plagiolepis, two from Morocco, one from the Iberian Peninsula are currently being described (in prep). These discoveries imply that parasitic Plagiolepis may be found wherever potential host species are abundant.

The ants from the Balearic Islands have been extensively studied (Saunders, 1901, 1904; Wheeler, 1926; Bernard, 1961; Comin \& De Haro, 1980; Comin \& Espadaler, 1984; De Haro et al., 1986; Comin, 1988), but no inquiline species have ever been reported. During a short visit (2.5 working days) we found three populations of $P$. xene Stärcke, parasitic on $P$. pygmaea (Latr.).

\section{LOCALITIES}

Plagiolepis xene was found at the following three sites: Station 1. Puig d'es Nogue, Mallorca, Spain. April 30, 1991. Grazed fire cut. $830 \mathrm{~m}$, NW slope with small flattened places with sparse vegetation of Smilax aspera, Asphodelus, Hypericum, Astragalus, Teucrium, Gladiolus and some isolated Pinus halepensis.

(1). Department de Biologia Animal, Biologia Vegetal i Ecologia. Universitat Autonoma de Barcelona. 08193 Bellaterra. Spain.

(2). Laboratoire d'Entomologie. Université Paul Sabatier. 118, route de Narbonne. 31062 Toulouse. France.

Manuscript received 18 November 1991. 
Plagiolepis pygmaea and P. xene were found under medium sized stones. Other ant species present (in order of abundance): Tetramorium semilaeve, Lasius niger, Tapinoma nigerrimum, Pheidole pallidula, Aphaenogaster subterranea, Hypoponera eduardi.

Station 2. km 57 on the road from Soller to Deya, Mallorca, Spain. May 1, 1991. 200m. Pine wood on steep slope facing NW. Underwood of Ampelodesma mauritanica, Cistus mospeliensis, Cistus albidus, Erica multiflora, Rhamnus, Asparagus, Lotus tetraphylus. Other ant species present: Lasius niger, Leptothorax "specularis", Camponotus sicheli, Camponotus scutellaris, Crematogaster laestrygon, Messor bouvieri.

Station 3. km 60 on the road from Deya to Valldemosa. Mallorca, Spain. May 1, 1991. 350m. Dense evergreen-oak forest; feeble slope facing NW-W. Very sparse underwood of Arbutus unedo, Ruscus aculeatus, Smilax aspera, Asparagus, Daphne, Cyclamen. Other ant species present: L. recedens, Lasius alienus, A. subterranea, C. scutellaris, P. pallidula, Colobopsis truncatus, Lasius niger and Hypoponera eduardi. It is worth mentioning that in the huge population of Leptothorax recedens no Epimyrma species was recovered.

\section{RESULTS}

During collection parasitic females could be detected because, as stones were turned over, they were always surrounded by a group of host workers. Several females were found in each group but no males were present in any nest at the time of collection. At Station 1 the host population was sufficiently dense to allow a tentative study of frequency of parasitization. Censuses made in four distinct places, several hundred meters apart, indicate that the parasites are extremely localized. They occupy a restricted surface of some $100 \mathrm{~m} 2$, thus showing an extremely contagious distribution. Single parasitized nests under medium sized stones were found in Station 2 (out of three host societies found) and Station 3 (out of four host societies).

Our $P$. xene collections were compared with Iberian samples. No morphological differences were detected in palps, mandible, pilosity and hypopygium. Likewise, no differences were detected between host specimens and Iberian P. pygmaea specimens. 


\section{DISCUSSION}

Though it is widely distributed (but rare) in France, Italy, Spain and Central Europe, the P. xene on Mallorca are most likely to have derived from populations on the Iberian Peninsula. Isolation of the Balearic Islands can be dated to the Messinian (Azzaroli and Guazzone, 1980; Hsu et al. 1973), some 5-5.5 million years BP, when Majorca was still in contact with the Iberian Peninsula.

The Balearic populations of $P$. xene inhabit biotopes that are not undisturbed or completely natural and, therefore, they cannot be considered relict populations. On the Iberian peninsula (unpublished data) samples of this species also come from the rather disturbed biotopes. This ant may be an exception to the usual rule that parasitic species are found in long-term stable, undisturbed biotopes. Because of this association with disturbed habitats, it is possible that $P$. xene has been imported to the Balearics in relatively recent times. A similar case of an imported inquiline ant has been reported for Anergates atratulus Schenck in North America (Brown, 1957) and it is interesting to note that both Plagiolepis pygmaea (host to P. xene) and Tetramorium caespitum (L.) (host to A. atratulus) inhabit more or less disturbed habitats.

\section{SUMMARY}

Plagiolepis xene Stärcke is the first inquiline ant reported from the Balearic Islands. Parasite populations may have become established in the Balearics relatively recently since they do not occur in undisturbed habitats.

\section{ACKNOWLEDGEMENTS}

To Prof. A. Buschinger for interesting suggestions; to Drs. J. Rosell, C. Llompart and J. Pons for useful comments on Balearic origins and Andrew Jones and an anonymous referee for corrections on the text.

\section{REFERENCES}

AzZARoli, A. AND GuAZZone, G.

1980. Terrestrial mammals and land connections in the Mediterranean before and during the Messinian. Palaeogeogr. Palaeoclim. Palaeoecol. 29: 155-167. 
BERNARD, F.

1961. Fourmis de Marjorque, de Corse et de sept petites iles du sud Mediterraneen. Coll. C.N.R.S. 94: 139-157.

1968. Les fourmis (Hymenoptera, Formicidae) d'Europe occidentale et BROWN, W. L. JR. septentrionale. Masson. Paris 411p.

1957. Is the ant Tetramorium native in North America?. Breviora 72: 1-8.

BUSCHINGER, A.

1987. Teleutomyrmex schneideri Kutter, 1950 and other parasitic ants found in the Pyrenees. Spixiana 10: 81-83.

Comin, P. ANd De HaRo, A.

1980. Datos iniciales para un estudio ecologico de las hormigas de Menorca. Bol. Soc. Hist. nat. Bal. 24: 23-48.

COMIN, P. AND ESPADALER, X.

1984. Ants of the Pityusic Islands. In: Biogeography and ecology of the

Comin, P. Pitysusic Island. editors. pp. 287-301. Junk, The Hague.

1988. Estudio de los Formicidos de Baleares. Ph.D. Thesis. Univ. Illes Balears.

De Haro, A., Collingwood, C. A. and Comin, P.

1986. Prospeccion mirmecologica por Ibiza y Formentera (Baleares). Orsis 2: 115-120.

EMERY, C.

1921. Notes critiques de myrmecologie. IX. Etude sur le genre Plagiolepis. Ann. Soc. ent. Belg. 61: 313-319.

Hsu, K. J., Ryan, W. B. F. AND Cita, M. B.

1973. Late Miocene dessication of the Mediterranean Sea. Nature 242: 240-244.

SANTSCHI, F.

1920. Cinc nouvelles notes sur les fourmis. Bull. Soc. Vaud. Sci. Nat. 53: 163-180.

SAUNDERS, E.

1901. Balearic insects. Hymenoptera Aculeata. Ent. Month. Mag. 12: 208-211.

1904. Hymenoptera Aculeata from Majorca and Spain. I. Majorca. Trans. ent. Soc. Lond. 1904: 596-598.

WHEELER, W. M.

1926. Ants of the Balearic Islands. Fol. Myrm. Term. 1: 1-6.

WILSON, E. O.

1955. A monographic revision of the ant genus Lasius. Bull. Mus. Comp. Zool. 113: 1-205.

1971. The Insect Societies. Belknap Press of Harvard University Press, Cambridge. 548. pp. 

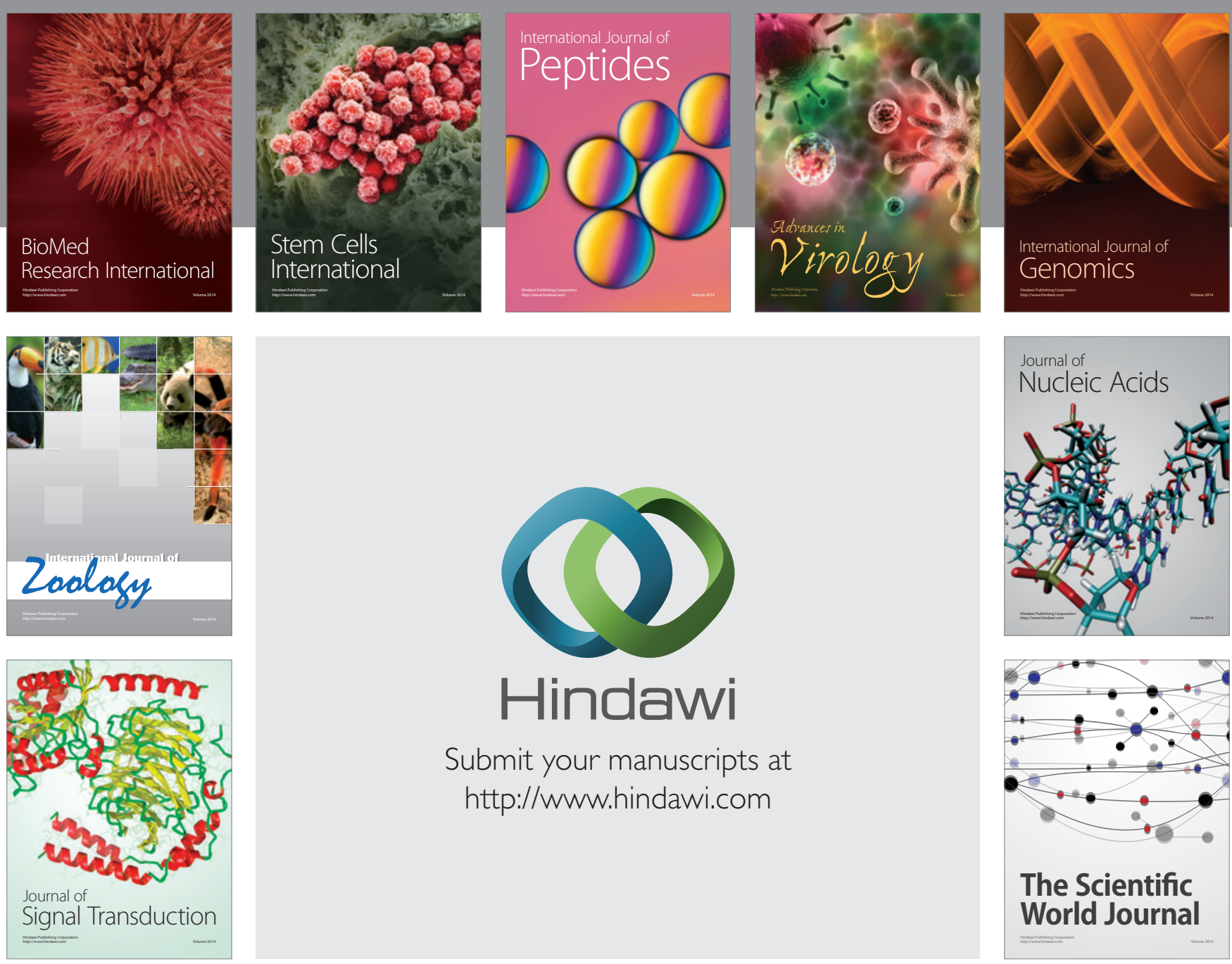

Submit your manuscripts at

http://www.hindawi.com
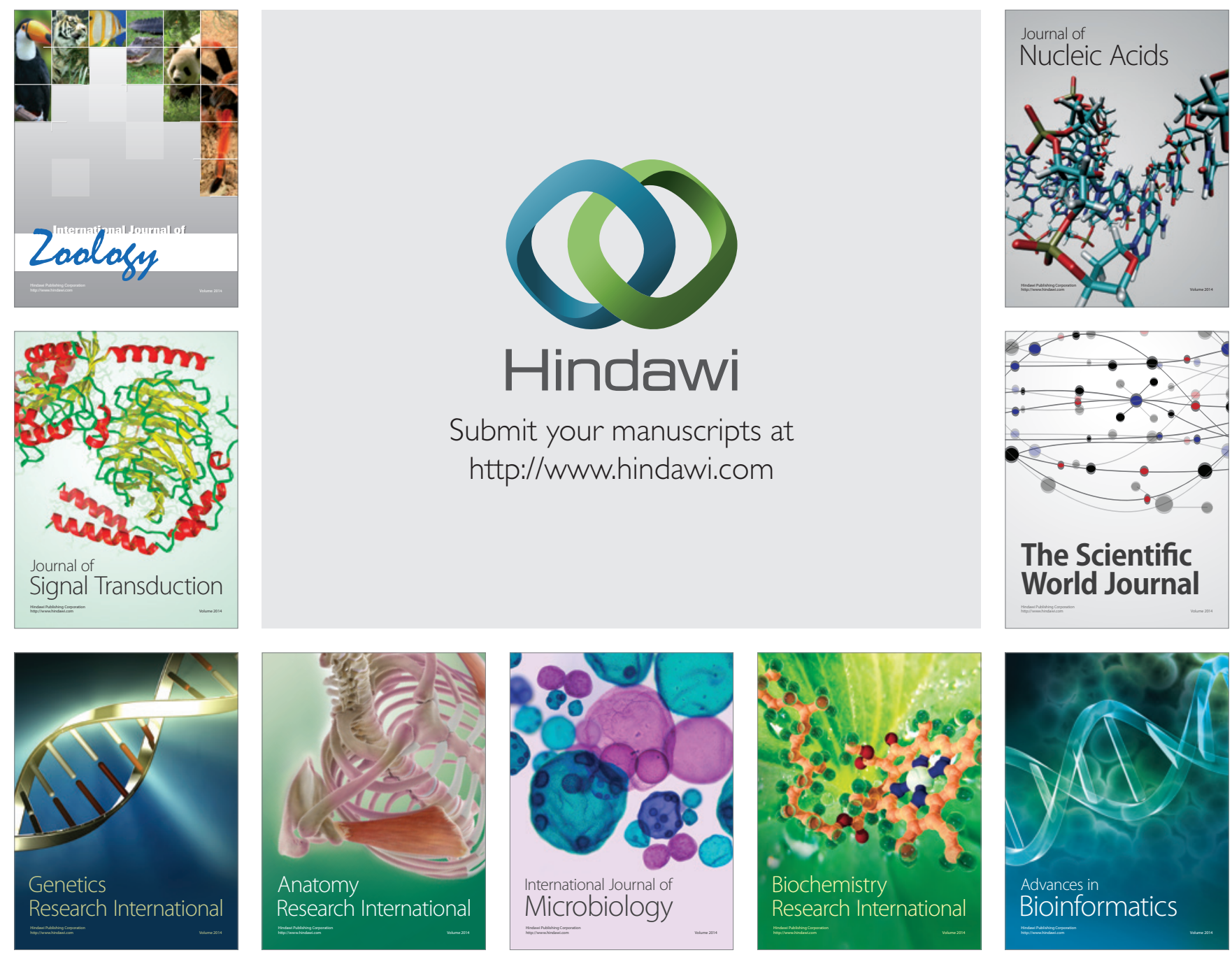

The Scientific World Journal
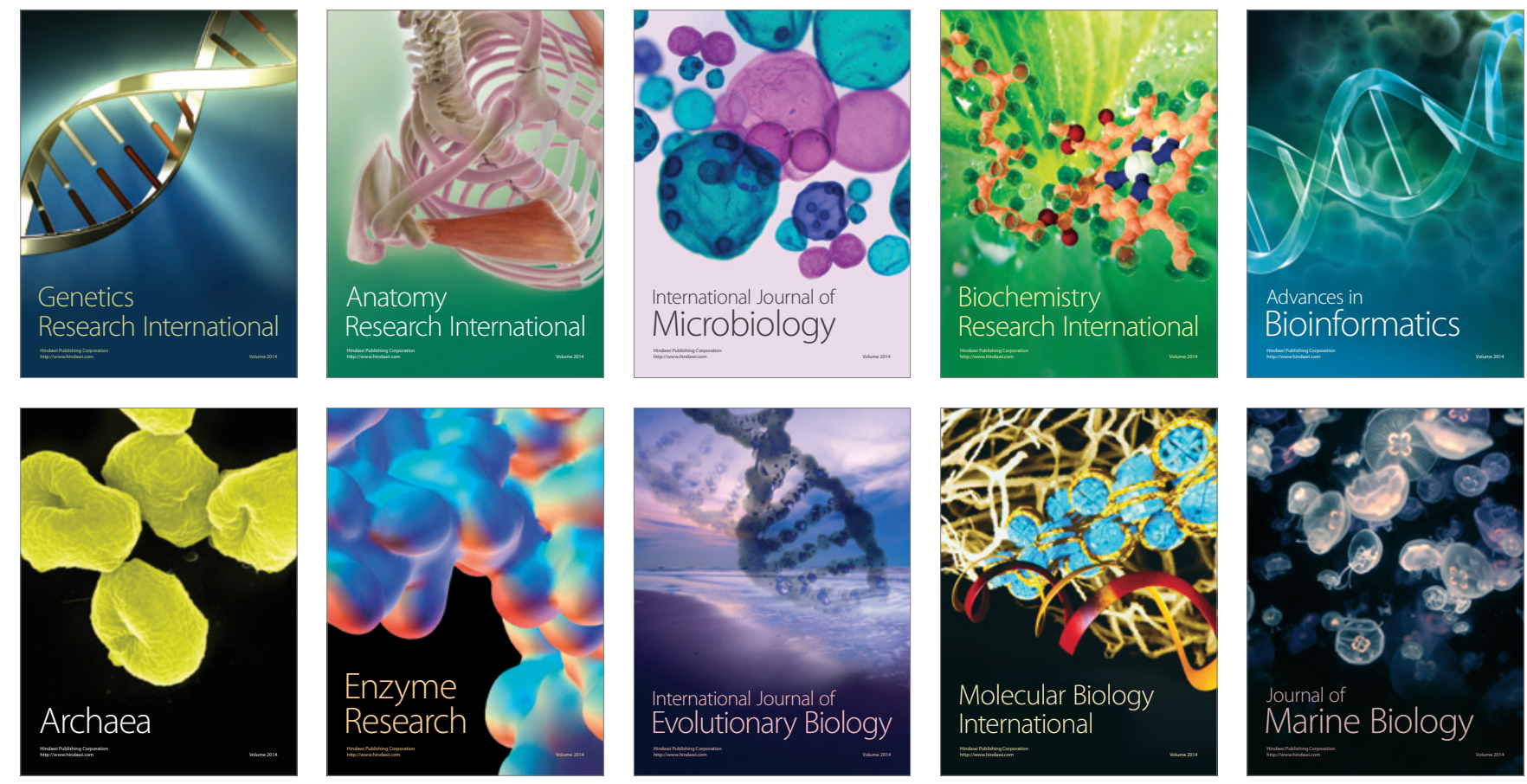